\title{
Evidence for Polyclonal Origin of Multifocal Clear Cell Renal Cell Carcinoma
}

\author{
Liang Cheng, ${ }^{1,2}$ Gregory T. MacLennan, ${ }^{3}$ Shaobo Zhang, ${ }^{1}$ Mingsheng Wang, ${ }^{1}$ Ming Zhou, ${ }^{4}$ \\ Puay-Hoon Tan, ${ }^{5}$ Stephanie Foster, ${ }^{1}$ Antonio Lopez-Beltran, ${ }^{6}$ and Rodolfo Montironi ${ }^{7}$
}

\begin{abstract}
Purpose: Renal cell carcinomas are often multifocal. We investigated the genomic signatures of multifocal clear cell renal cell carcinoma to determine whether multiple tumors in the same kidney bear a clonal relationship to one another.

Experimental Design: A total of 62 tumors from 26 patients who underwent radical nephrectomy were examined. All patients had multiple separate clear cell renal carcinomas. Loss of heterozygosity analyses were done using five microsatellite polymorphic markers that represent putative tumor suppressor genes on chromosome 3p14 (D3S1300), 7q31 (D7S522), 8p22 (D8S261), 9p21 (D9S171), and 17p13 (TP53). X chromosome inactivation analyses were also done on the renal tumors from the 10 female patients. Chromosome $3 p$ deletion status was determined by dual color interphase fluorescence in situ hybridization analysis in all tumors.

Results: Nineteen of the 26 (73\%) patients with multifocal clear cell renal cell carcinoma showed allelic loss in at least 1 of 5 microsatellite loci in separate tumors analyzed. A disconcordant pattern of allelic loss between coexisting kidney tumors was observed in 7 cases. Six cases showed discordant $3 p$ deletion patterns by dual color interphase fluorescence in situ hybridization analysis. Of the eight informative female cases studied by $X$ chromosome inactivation, one showed a discordant nonrandom pattern of $X$ chromosome inactivation. Overall, evidence of independent origin of the multifocal renal tumors was observed in 12 of 26 cases (46\%).

Conclusions: Our data suggest that in a significant number of cases of multifocal clear cell renal cell carcinoma, the spatially separate tumors are of different clonal origin and arise independently.
\end{abstract}

Approximately $5 \%$ to $25 \%$ of patients undergoing radical nephrectomy for renal cell carcinoma harbor multifocal tumors at the time of diagnosis $(1-7)$. Because conventional chemotherapeutic agents are largely unsuccessful against renal cell carcinoma, surgical extirpation is regarded as the most effective means of treatment. In recent years, more conservative nephron sparing surgery, as an alternative to traditional radical nephrectomy, has gained popularity $(8-10)$. With the increased use of nephron sparing surgical excision of renal neoplasms, concern has been expressed that limited surgical

\footnotetext{
Authors' Affiliations: Departments of ${ }^{1}$ Pathology and Laboratory Medicine and ${ }^{2}$ Urology, Indiana University School of Medicine, Indianapolis, Indiana; ${ }^{3}$ Department of Pathology, Case Western Reserve University and ${ }^{4}$ Department of Pathology, Cleveland Clinic, Cleveland, Ohio; ${ }^{5}$ Department of Pathology, Singapore General Hospital, Singapore; ${ }^{6}$ Department of Pathology, Cordoba University, Cordoba, Spain; and ${ }^{7}$ Institute of Pathological Anatomy and Histopathology, School of Medicine, Polytechnic University of the Marche Region (Ancona), United Hospitals, Ancona, Italy

Received 6/11/08; revised 8/18/08; accepted 8/18/08.

The costs of publication of this article were defrayed in part by the payment of page charges. This article must therefore be hereby marked advertisement in accordance with 18 U.S.C. Section 1734 solely to indicate this fact.

Note: Supplementary data for this article are available at Clinical Cancer Research Online (http://clincancerres.aacrjournals.org/).

Requests for reprints: Liang Cheng, Department of Pathology and Laboratory Medicine, Indiana University School of Medicine, 350 West 11th Street, Clarian Pathology Laboratory Room 4010, Indianapolis, IN 46202. Phone: 317-491-6442; Fax: 317-491-6419; E-mail: liang_cheng@yahoo.com

(C) 2008 American Association for Cancer Research.

doi:10.1158/1078-0432.CCR-08-1494
}

resections may not encompass multifocal renal cell tumors, specifically those that are too small to be visualized radiologically, with the result that such unresected tumors would ultimately require additional treatment $(1,4,9,11)$. Consequently, a clear understanding of the genetic relationships between multifocal renal tumors in the same patient and a reasonably accurate knowledge of the malignant potential of each lesion could have important diagnostic, therapeutic, and prognostic implications.

Clear cell renal cell carcinoma (CCRCC) is the most common type of malignant neoplasm that arises in the kidney, accounting for $70 \%$ to $80 \%$ of cases $(12,13)$. Previous investigators, based on their findings, have hypothesized that multifocal renal cancers of clear cell type are monoclonal, and that so-called satellite neoplasms represent intrarenal metastases $(14,15)$. However, there is strong clinical evidence that multifocal renal cell carcinomas may arise independently rather than through intrarenal metastasis, as the monoclonal theory implies (1-7). The presence of multifocality may be a consequence of "field effect" during renal carcinogenesis, with subsequent risk for tumor recurrence. Patients with multifocal CCRCCs have a higher risk of developing contralateral CCRCC, synchronously or metachronously, than patients with unilateral solitary CCRCCs $(16,17)$. The presence of multifocality does not correlate with a significantly increased risk of cancer progression and metastasis, a finding that argues against the likelihood of intrarenal metastasis as an explanation for this finding in such cases $(7,17,18)$. 


\section{Translational Relevance}

In the current study, we investigated 26 patients with multifocal clear cell renal cell carcinoma using loss of heterozygosity, $\mathrm{X}$ chromosome inactivation, and interphase fluorescence in situ hybridization to assess tumor clonality. Nearly half $(46 \%)$ of the tumors examined displayed discordant allele loss patterns, discordant nonrandom $X$ chromosome inactivation patterns, or discordant $3 p$ deletion status, consistent with the concept that these separate renal tumors represent clonal neoplasms of independent origin, rather than a primary tumor with intrarenal metastases. Elucidation of tumor clonality is potentially important in assessing therapeutic options and prognosis in cases of multifocal clear cell renal cell carcinoma.

In our previous study (19), we showed that the multiple tumors in patients with papillary renal cell carcinoma arise independently. Understanding the nature of tumor multifocality and clonal origin of renal tumors may further our understanding of the genetic basis of tumor progression and provide biological insights for cancer treatment and prognosis. In the current study, we assessed the clonal relationships between 62 coexisting, separate tumors from 26 patients diagnosed with multifocal CCRCC, using loss of heterozygosisty (LOH), X chromosome inactivation, and interphase fluorescence in situ hybridization (FISH) analyses of chromosome 3 p deletion.

\section{Materials and Methods}

Patients. Sixteen men and 10 women $(n=26)$ with multifocal renal tumors underwent surgery from 1995 to 2006 at the participating institutions. Patients had a mean age of 59 y (range, 21-84 y). All patients had two or more renal tumors diagnosed histologically as CCRCC (Fig. 1). Twenty-one synchronous cases ( $>2$ tumors coexisting at the time of surgery, and the 2 tumors located at least $1 \mathrm{~cm}$ apart) and 5 metachronous cases (1 or more tumors were surgically removed with a time interval after the first renal surgery) were included in this study. In five cases, bilateral tumors were observed. Pathologic stage was assigned according to the 2002 tumor-nodemetastasis classification system (20) and histologic grade was assigned using the Fuhrman nuclear grading system (21).

Tissue samples and microdissection. Histologic sections were prepared from formalin-fixed, paraffin-embedded tissue and were stained with H\&E for microscopic evaluation (Fig. 1). These slides were examined microscopically to confirm that CCRCC was present. Laser capture microdissection of the tumors was done on corresponding unstained sections using a PixCell II Laser-Capture Microdissection system (Acturus Engineering) as previously described (22-25). Approximately 600 to 1,000 cells of each tumor were microdissected from the $4-\mu \mathrm{m}$ histologic sections. This number of cells yields $\sim 4$ to 6 ng genomic DNA. Similar numbers of normal cells were microdissected from each specimen for use as controls.

Detection of loss of heterozygosity. The genomic DNAs were extracted from microdissected cells $(22,26,27)$. PCR was used to amplify genomic DNA at five specific loci on five different chromosomes: 3p14 (D3S1300), 7q31 (D7S522), 8p22 (D8S261), 9p21 (D9S171), and 17p13 (TP53; refs. 28-31). Previous studies have shown that $\mathrm{LOH}$ at these loci frequently occurs in renal cell carcinomas(28-31). PCR amplification and gel electrophoresis were done as previously described $(32-37)$. Approximately 100 to $200 \mathrm{pg}$ of genomic DNA was used as template for PCR. We recognized that the amount of template used for $\mathrm{LOH}$ analysis was critical to reliably perform PCR (38). The use of $\alpha{ }^{32}[\mathrm{P}]$-dATP incorporation PCR has shown to increase the sensitivity compared with the fluorescencelabeled PCR method; also, the sensitivity could be adjusted by exposure time.

The criterion for allelic loss was complete or nearly completes absence of one allele in tumor DNA $(19,35)$. PCRs for each polymorphic microsatellite marker were repeated at least twice from the same DNA preparations and the same results were obtained.

Detection of X chromosome inactivation. X chromosome inactivation analysis was done on all tumors from female patient, as previously described (35). Eight-microliter aliquots of the DNA extract were digested overnight at $37^{\circ} \mathrm{C}$ with $1 \mathrm{U}$ of $\mathrm{Hha}$ I restriction endonuclease (New England Biolabs, Inc.) in a total volume of $10 \mu \mathrm{L}$. Control reactions for each sample were incubated in the digestion buffer without $H$ ha I endonuclease. After the incubation, $3 \mu \mathrm{L}$ of digested and nondigested DNA was amplified in a $25 \mu \mathrm{L}$ PCR reaction containing $0.1 \mu \mathrm{L} \alpha-{ }^{32}[\mathrm{P}]$-labeled dATP $(3,000 \mathrm{Ci} / \mathrm{mmol} / \mathrm{L}), 4 \mu \mathrm{mol} / \mathrm{L}$ of each AR-primers(39), 4\% DMSO, $2.5 \mathrm{mmol} / \mathrm{L} \mathrm{MgCl}_{2}, 300 \mu \mathrm{mol} / \mathrm{L}$ each deoxynucleotide triphosphate, and $0.65 \mathrm{U}$ Taq DNA polymerase (Perkin-Elmer). Each PCR amplification had an initial denaturation at $95^{\circ} \mathrm{C}$ for $8 \mathrm{~min}$, followed by 38 cycles at $95^{\circ} \mathrm{C}$ for $40 \mathrm{~s}, 63^{\circ} \mathrm{C}$ for $40 \mathrm{~s}$, and $72^{\circ} \mathrm{C}$ for $60 \mathrm{~s}$, then followed by a single extension step at $72^{\circ} \mathrm{C}$ for $10 \mathrm{~min}$. The PCR product was separated by denatured polyacrylamide gel and visualized by autoradiography.

Analysis of $X$ chromosome inactivation. The cases were considered to be informative if two androgen receptor allelic bands were detected after PCR amplification in normal control samples that had not been treated with Hha I $(22,40)$. Only informative cases were included in the analysis. In tumor samples, nonrandom $\mathrm{X}$ chromosome inactivation was defined as complete or nearly complete absence of one AR allele after Hha I digestion, which indicated a predominant methylation of one allele (nonrandom inactivation) in the cellular population. Tumors were considered to be of the same clonal origin if identical nonrandom androgen receptor allelic inactivation patterns were detected in each separate tumor. Tumors were considered to be of independent origin if the dissimilar predominance of androgen receptor alleles after Hha I digestion (different allelic inactivation patterns) was detected in each tumor $(22,40,41)$.

FISH. FISH methods as described previously $(19,42)$. Briefly, 4- $\mu \mathrm{m}$ tissue sections were prepared from buffered formalin-fixed, paraffin-embedded tissue blocks containing tumor. The slides were deparaffinized with two washes of xylene, $15 \mathrm{~min}$ each, and subsequently washed twice with absolute ethanol, $10 \mathrm{~min}$ each and then air dried in the hood. FISH was done with centromeric $\alpha$-satellite DNA probes for chromosome 3 (CEP3; Spectrum Orange) and subtelomeric probe for 3p25 (3pTel25; Spectrum Green). The probes were from Vysis (Downers Grove) and were diluted with $t$ DenHyb 2 (Insitus) in a ratio of 1:100. The slides were examined using a Zeiss Axioplan 2 microscope (ZEISS) with the following filters from Chroma (Chroma): SP-100 for 4',6-diamidino-2-phenylindole, FITC MF-101 for Spectrum Green (3pTel25) and Gold 31003 for Spectrum Orange (CEP 3). The images were acquired with a charge-coupled device camera and analyzed with MetaSystem Isis Software (MetaSystem). Five sequential focus stacks with 0.4-mm intervals were acquired and then integrated into a single image to reduce thickness-related artifacts.

The method of in situ hybridization analysis was partially described previously $(42-51)$. In brief, for each slide, 100 to 150 nonoverlapping nuclei from tumor tissue were scored for signals from each probe under the fluorescence microscope with $\times 1,000$ magnification. The ratio of $3 \mathrm{p} / \mathrm{CEP} 3$ signals was determined. The method to analyze $3 \mathrm{p}$ deletion was based on previous studies of deletion of chromosomes $1 \mathrm{p}$ and $19 \mathrm{q}$ in oligodendrogliomas $(52,53)$. The cutoff value for $3 p$ deletion was defined as a $3 \mathrm{p} / \mathrm{CEP} 3$ ratio of $<0.7$, as previously described $(42-46,50,51)$. 


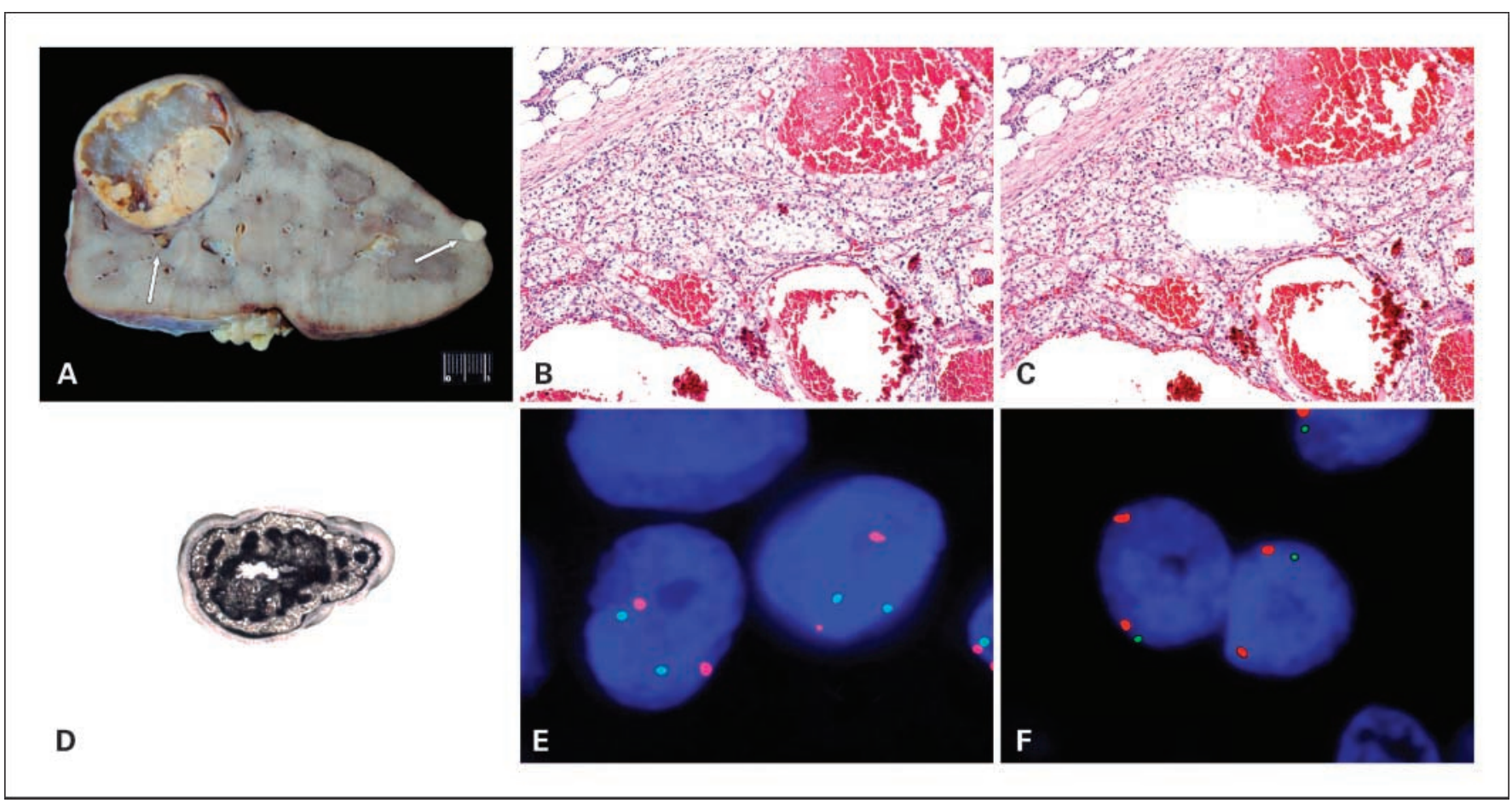

Fig. 1. Gross appearance, histology, laser capture microdissection, and FISH images of multifocal clear cell carcinoma. $A$, representative gross appearance of multifocal CCRCC $(A)$ shows the tumors are confined in the kidney and located at least $1 \mathrm{~cm}$ apart. $B$, typical histology of CCRCC $(B)$. $C$ and $D$, laser capture microdissection of the same cancer tissue $(C)$ and the tissue isolated $(D)$. E, disomic cancer cells showed two red signals (CEP3) and three green signals $(3 p)$; $F$, cancer cells with chromosome arm $3 p$ deletion showed two red signals and only one green signal.

Statistical analysis. Correlations between genetic alterations and different clinical variables were analyzed using Pearson/Spearman correlation test. A $P$ value of 0.05 was considered significant, and all $P$ value tests were two sided.

\section{Results}

Clinicopathologic characteristics. A total of 62 separate tumors from 16 men and 10 women were analyzed in this study. Sixteen patients (62\%) were males and $10(38 \%)$ were females. The clinical data of patients are summarized in Table 1 . The pathologic stages of the carcinomas were as follows: T1, 25 tumors (40\%); T2, 5 tumors (8\%); and T3, 32 tumors $(52 \%)$. The majority of coexisting tumors showed a comparable tumor stage. Forty-eight tumors from 21 patients occurred synchronously, and 14 tumors from 5 patients were of metachronous onset. The Fuhrman nuclear grade of individual tumors was as follows: grade 1, 3 tumors (4\%); grade 2, 27 tumors (44\%); grade 3, 24 tumors (39\%); and grade 4,8 tumors $(13 \%)$.

LOH. In 19 of the 26 patients with multifocal CCRCC $(73 \%)$, allelic loss was shown in 1 or more of the separate tumors in at least 1 of the 5 loci analyzed (Supplementary Table S1; Fig. 2). The frequencies of allelic loss in the informative CCRCCs were $17 \%$ (4 of 24) with D3S1300, $29 \%$ (7 of 24) with D7S522, 22\% (5 of 23) with D8S261, 24\% (6 of 25 ) with D9S171, and 46\% (11 of 24) with TP53. The number of specific loci lost in a single tumor ranged from one to three. A disconcordant pattern of allelic loss between coexisting kidney tumors was observed in seven cases.

$X$ chromosome inactivation analysis. X chromosome inactivation analysis was done in 10 female patients. Eight cases showed nonrandom pattern of $\mathrm{X}$ chromosome inactivation; two cases were noninformative. One case (case 16) showed a discordant nonrandom $\mathrm{X}$ chromosome inactivation pattern, whereas tumors from the other 7 informative female cases showed concordant nonrandom $\mathrm{X}$ chromosome inactivation patterns (Fig. 2).

FISH. FISH analysis was done on all 62 tumors from 26 patients for chromosome $3 \mathrm{p}$ and the centromere of chromosome 3 (Fig. 1E and F). Chromosome 3p deletion was observed in 55 tumors (89\%). Tumors from 20 cases $(77 \%)$ showed similar chromosome $3 p$ deletion patterns, whereas tumors in 6 cases $(23 \%)$ showed discordant chromosome 3p deletion patterns (Supplementary Table S1).

In total, 3 of 5 bilateral tumors showed shown discordant allele loss patterns, discordant nonrandom $\mathrm{X}$ chromosome inactivation patterns, or discordant chromosome $3 p$ deletion patterns.

Correlations between genetic alterations and clinicopathologic variables. We correlated molecular genetic alterations with various clinical and pathologic variables. There was no correlation between $\mathrm{LOH} /$ chromosome $3 \mathrm{p}$ deletion and other clinicopathologic characteristics such as patient age, gender, histologic grade, and tumor stage (all $P>0.05$ ).

\section{Discussion}

Radical nephrectomy has long been considered the gold standard of surgical therapy for renal cell carcinoma. With advances in radiologic imaging, an increasing proportion of renal cancers are detected incidentally, and a high proportion of these tumors are small. As a result, nephron sparing surgical 
Table 1. Clinicopathologic characteristics

\begin{tabular}{|c|c|c|c|c|c|c|}
\hline Case no & Age/sex & Tumor foci & Meta/synchronous & Tumor stage & Fuhrman nuclear grade & Laterality \\
\hline \multirow[t]{4}{*}{1} & $77 / M$ & $\mathrm{~F} 1$ & $\mathrm{~S}$ & T3 & 4 & $\mathrm{R}$ \\
\hline & & $\mathrm{F} 2$ & & & 4 & \\
\hline & & F3 & & & 4 & \\
\hline & & $\mathrm{F} 4$ & & & 4 & \\
\hline \multirow[t]{2}{*}{2} & $55 / F$ & $\mathrm{~F} 1$ & $\mathrm{~S}$ & T3 & 2 & L \\
\hline & & $\mathrm{F} 2$ & & & 2 & \\
\hline \multirow[t]{2}{*}{3} & $48 / M$ & $\mathrm{~F} 1$ & $\mathrm{~S}$ & $\mathrm{~T} 1$ & 2 & $\mathrm{R}$ \\
\hline & & $\mathrm{F} 2$ & & & 2 & \\
\hline \multirow[t]{2}{*}{4} & $46 / M$ & $\mathrm{~F} 1$ & M & T3 & 2 & $\mathrm{R}$ \\
\hline & & $\mathrm{F} 2$ & & T3 & 3 & L \\
\hline \multirow[t]{2}{*}{5} & $62 / M$ & $\mathrm{~F} 1$ & S & T3 & 2 & $\mathrm{R}$ \\
\hline & & $\mathrm{F} 2$ & & & 2 & \\
\hline \multirow[t]{2}{*}{6} & $65 / M$ & $\mathrm{~F} 1$ & $\mathrm{~S}$ & T3 & 3 & $\mathrm{R}$ \\
\hline & & $\mathrm{F} 2$ & & & 3 & \\
\hline \multirow[t]{2}{*}{7} & $41 / M$ & $\mathrm{~F} 1$ & $\mathrm{~S}$ & T1 & 2 & $\mathrm{R}$ \\
\hline & & F2 & & & 2 & \\
\hline \multirow[t]{2}{*}{8} & $45 / M$ & $\mathrm{~F} 1$ & $\mathrm{~S}$ & $\mathrm{~T} 1$ & 2 & $\mathrm{R}$ \\
\hline & & F2 & & & 2 & \\
\hline \multirow[t]{2}{*}{9} & $47 / M$ & $\mathrm{~F} 1$ & $\mathrm{~S}$ & T3 & 3 & $R$ \\
\hline & & F2 & & & 3 & \\
\hline \multirow[t]{2}{*}{10} & $55 / M$ & $\mathrm{~F} 1$ & $\mathrm{~S}$ & T2 & 2 & L \\
\hline & & F2 & & & 2 & \\
\hline \multirow[t]{2}{*}{11} & $84 / M$ & $\mathrm{~F} 1$ & $\mathrm{~S}$ & T3 & 4 & $\mathrm{R}$ \\
\hline & & F2 & & & 4 & \\
\hline \multirow[t]{3}{*}{12} & $79 / M$ & $\mathrm{~F} 1$ & $S$ & T3 & 3 & $\mathrm{R}$ \\
\hline & & F2 & & & 3 & \\
\hline & & F3 & & & 3 & \\
\hline \multirow[t]{2}{*}{13} & $82 / M$ & $\mathrm{~F} 1$ & $\mathrm{~S}$ & $\mathrm{~T} 2$ & 4 & L \\
\hline & & F2 & & & 4 & \\
\hline \multirow[t]{3}{*}{14} & $72 / M$ & $\mathrm{~F} 1$ & S & T1 & 3 & L \\
\hline & & F2 & & & 3 & \\
\hline & & F3 & & & 3 & \\
\hline 15 & $46 / M$ & $\mathrm{~F} 1$ & $S$ & T3 & 2 & L \\
\hline & & F2 & & & 2 & \\
\hline 16 & $72 / F$ & $\mathrm{~F} 1$ & $M$ & $\mathrm{~T} 2$ & 3 & $R$ \\
\hline & & F2 & & T3 & 2 & L \\
\hline 17 & $37 / F$ & $\mathrm{~F} 1$ & $M$ & $\mathrm{~T} 1$ & 3 & $\mathrm{R}$ \\
\hline & & F2 & & $\mathrm{T} 1$ & 2 & $\mathrm{~L}$ \\
\hline 18 & $21 / \mathrm{F}$ & $\mathrm{F} 1$ & $M$ & $\mathrm{~T} 1$ & 1 & $R$ \\
\hline & & F2 & & & 2 & \\
\hline & & F3 & & $\mathrm{T} 1$ & 2 & L \\
\hline 19 & $72 / F$ & $\mathrm{~F} 1$ & $\mathrm{~S}$ & $\mathrm{~T} 1$ & 2 & $\mathrm{R}$ \\
\hline & & F2 & & & 3 & \\
\hline 20 & $34 / F$ & $\mathrm{~F} 1$ & $M$ & $\mathrm{~T} 1$ & 2 & $R$ \\
\hline & & F2 & & & 2 & \\
\hline & & F3 & & & 2 & \\
\hline & & F4 & & & 2 & \\
\hline & & F5 & & $\mathrm{T} 1$ & 3 & L \\
\hline 21 & $29 / F$ & $\mathrm{~F} 1$ & $S$ & $\mathrm{~T} 1$ & 1 & L \\
\hline & & $\mathrm{F} 2$ & & & 1 & \\
\hline 22 & $77 / F$ & $\mathrm{~F} 1$ & $\mathrm{~S}$ & T3 & 3 & $\mathrm{R}$ \\
\hline & & F2 & & & 3 & \\
\hline 23 & $79 / F$ & $\mathrm{~F} 1$ & $\mathrm{~S}$ & $\mathrm{~T} 1$ & 3 & L \\
\hline & & F2 & & & 3 & \\
\hline 24 & $81 / \mathrm{F}$ & $\mathrm{F} 1$ & S & T3 & 3 & L \\
\hline & & F2 & & & 3 & \\
\hline 25 & $65 / M$ & $\mathrm{~F} 1$ & S & T3 & 3 & $\mathrm{~L}$ \\
\hline & & F2 & & & 3 & \\
\hline & & F3 & & & 3 & \\
\hline 26 & $53 / M$ & $\mathrm{~F} 1$ & S & T3 & 2 & $\mathrm{R}$ \\
\hline & & F2 & & & 2 & \\
\hline & & F3 & & & 2 & \\
\hline
\end{tabular}

Abbreviations: F, different tumor focus; M, metachronous; S, synchronous; L, left kidney; R, right kidney. 
techniques have become popular for renal cancer therapy, even in patients with normally functioning contralateral kidneys. Some authors have expressed concern that conservative surgery for renal cell carcinoma may predispose the patient to local recurrence due to the presence of residual small potentially malignant tumors in the unresected renal tissue. Additional tumors undetectable by conventional radiologic examination have been found in $13 \%$ to $25 \%$ of kidneys resected by radical nephrectomy (4-6). Local tumor recurrence after nephron sparing surgery may be due to incomplete resection of the primary tumor, remaining multicentric lesions, or the development of new primary or metastatic foci of renal cell carcinoma in the renal remnant $(1,9)$. Better understanding of the clonal relationships between multifocal tumors may be of importance for patient management. Multiple tumors that arise independently due to "field effect" (polyclonal tumors) may be associated with a better prognosis than multiple tumors that result from intrarenal metastasis of a biologically more aggressive neoplasm that has attained the capablity for metastasis (monoclonal tumors).

A rational approach to the assessment of multifocal renal tumors requires a clear understanding of the biological nature and molecular signatures of the individual renal neoplasms $(2,54)$. Previous studies $(14,15)$ of multifocal CCRCCs examined the possible monoclonal basis of these types of renal cancer, focusing primarily on microsatellite analyses of chromosome 3p. Their findings led these investigators to propose that in most cases multifocal clear cell and nonpapillary lesions
Fig. 2. Representative results of loss of heterozygosity $(A)$ and $\mathrm{X}$ chromosome inactivation $(B)$ analysis. DNA sample was prepared from normal tissue $(N)$ and separate tumor loci (F1, F2, etc.) amplified by PCR using microsatellite markers $(A)$ or human androgen receptor gene (HUMARA) locus primers $(B)$ and separated by PAGE. $A$, typical discordant patterns of $\mathrm{LOH}$ in D3S1300 (case 16), D7S522 (case 5), and concordant LOH pattern in D7S522 (case 2), D8S261 (case 14), D9S171 (case 5), and TP53 (case 5 and 16). Normal informative LOH patterns (no allelic loss) were also seen in D3S1300 (left), D8S261 (left), and D9S171 (right). B, both discordant (case 16) and concordant (case 23) patterns nonrandom X chromosome inactivation. Arrows, allelic bands. -, without Hhal digestion; +, with Hhal digestion. Numbers under the gel picture, case numbers (see Supplementary Table S1 and Table 1).

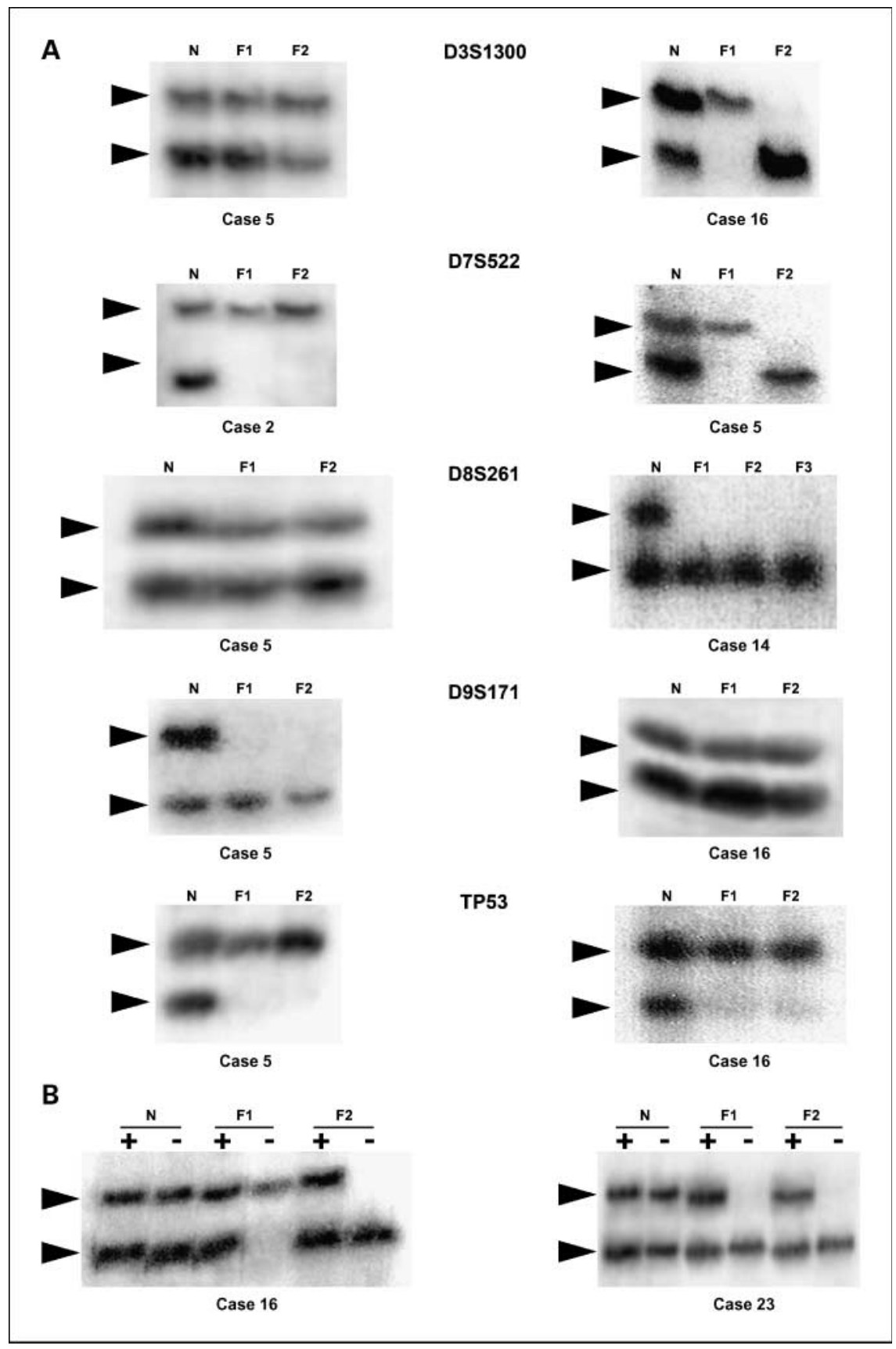


are the result of intrarenal metastases. Miyake et al. (14) implied that nephron sparing surgery might be inadequate, and might entail a risk of failure to prevent postoperative local tumor recurrence due to incomplete resection of unrecognized metastatic cancers in the residual kidney, bearing the same malignant characteristics as the resected primary tumor. It is interesting to note that, in Junker's study (15), only $13(68 \%)$ of the 19 cases seemed to possess concordant LOH patterns, whereas the remaining 6 revealed discordant patterns of allelic loss. Neither of the above studies examined $\mathrm{X}$ chromosome inactivation status of the tumors, or used other cytogenetic investigations such as FISH.

Although previous reports in the literature seem to conclude that multifocal CCRCC arise from a single clone, there was actually discordant LOH on chromosome 3p (15). Miyake et al. (14) reported discordant $\mathrm{LOH}$ in 2 of 10 cases (20\%). Thus, these earlier reports presented evidence supporting independent clonal origin in some cases of multiple clear cell renal tumors from the same patient. Our current work extends and expands these observations. Using the combination of $\mathrm{LOH}, \mathrm{X}$ chromosome inactivation, and interphase FISH, we showed that nearly half of cases of multifocal CCRCC may arise independently. Different patterns of nonrandom X chromosome inactivation in separate tumors, which is unequivocal evidence of independent clonal origin, was first reported in the current study.

Several caveats should be mentioned. $\mathrm{LOH}$ has been widely regarded as a marker of clonality because $\mathrm{LOH}$ is presumably an early event during tumorigenesis (41). When comparing different tumors, concordant patterns of LOH on multiple loci is consistent with common clonal origin of the tumors; in contrast, discordant patterns of $\mathrm{LOH}$ are compatible with independent origin of the tumors. Nonetheless, LOH may also represent differential tumor progression in satellite tumors arising from a single clone. In the current study, there were discrepancies between 3p deletions by LOH and FISH analysis. These discrepancies may be due to divergence of methodology, microsatellite markers analyzed, and different patient populations. FISH analyses detect large fragment alterations, whereas LOH studies detect genetic alterations at the allelic level. We analyzed the microsatellite locus D3S1300 at 3p14.2, but the FISH probe targets 3p25, covering the region of VHL gene. Chromosomal segment loss during the process of carcinogenesis may be variable. If the loss is downstream of D3S1300 (without involve of D3S1300), it will show 3p deletion by FISH without LOH on D3S1300. If the loss was from upstream of D3S1300, the case may show both LOH and 3p deletion.

In the current study, we investigated 26 patients with multifocal CCRCC using loss of heterozygosity, X chromosome inactivation, and interphase FISH to assess tumor clonality. Nearly half of the tumors examined displayed discordant allele loss patterns, discordant nonrandom $\mathrm{X}$ chromosome inactivation patterns, or discordant $3 p$ deletion status, consistent with the concept that these separate tumors occurring in the same or opposite kidneys, synchronously or metachronously, represent clonal neoplasms of independent origin, rather than a primary tumor with one or more intrarenal or extrarenal metastases. Our observations did not support the notion that the underlying biological basis of CCRCC multifocality in the great majority of instances is intrarenal metastasis of primary tumors. Our findings refute the contention that nearly all cases of multifocal CCRCC are of monoclonal origin, and show that a large proportion of cases of multifocal CCRCC are not clonally related, arise independently, and, thus, are not a result of intrarenal metastasis. We recommend that the terms "satellite" or "secondary tumors" should not be used because they imply intrarenal metastasis. Our data support the current clinical practice of nephron sparing surgery in patients with multifocal CCRCC, when technically feasible. The likelihood of a field effect of renal carcinogenesis in a large proportion of such patients emphasizes the need for close and ongoing surveillance for the development of new renal neoplasms.

The precise mechanisms responsible for the independent and multicentric origin of CCRCC are currently unknown. A better understanding of their clonality is potentially important in assessing therapeutic options and prognosis in cases of multifocal CCRCC.

\section{Disclosure of Potential Conflicts of Interest}

No potential conflicts of interest were disclosed

\section{References}

1. Raz O, Mendlovic S, Leibovici D, et al. The prevalence of malignancy in satellite renal lesions and its surgical implication during nephron sparing surgery. J Urol 2007;178:1892-5.

2. Cohen HT, McGovern FJ. Renal-cell carcinoma. N Engl J Med 2005;353:2477-90.

3. Hafez KS, Fergany AF, Novick AC. Nephron sparing surgery for localized renal cell carcinoma: impact of tumor size on patient survival, tumor recurrence and TNM staging. J Urol 1999;162:1930-3.

4. Cheng WS, Farrow GM, Zincke $H$. The incidence of multicentricity in renal cell carcinoma. J Urol 1991; 146:1221 - 3 .

5. Nissenkorn I, Bernheim J. Multicentricity in renal cell carcinoma. J Urol 1995:153:620-2.

6. Mukamel E, Konichezky M, Engelstein D, Servadio C. Incidental small renal tumors accompanying clinically overt renal cell carcinoma. J Urol 1988:140:22-4.

7. Richstone L, Scherr DS, Reuter VR, et al. Multifocal renal cortical tumors: frequency, associated clinicopathological features and impact on survival. J Uro 2004;171:615-20.

8. Aron M, Gill IS. Minimally invasive nephron-sparing surgery (MINSS) for renal tumours part I: laparoscopic partial nephrectomy. Eur Urol 2007;51:337-47.

9. Uzzo RG, Novick AC. Nephron sparing surgery for renal tumors: indications, techniques and outcomes. J Urol 2001;166:6-18.

10. Lane BR, Gill IS. 5-Year outcomes of laparoscopic partial nephrectomy. J Urol 2007;177:70-4.

11. Whang $M, O$ 'Toole $K$, Bixon $R$, et al. The incidence of multifocal renal cell carcinoma in patients who are candidates for partial nephrectomy. J Urol 1995;154: $968-71$.

12. MacLennan GT, Cheng L. Neoplasms of the kidney. In: Bostwick DG, Cheng L, editors. Urologic Surgical Pathology. 2nd ed. Philadelphia: Mosby/Elsevier; 2008. p. 77-172.

13. Eble JN, Sauter G, Epstein JI, Sesterhenn IA. World Health Organization: Pathology and Genetics. Tumours of the Urinary System and Male Genital Organs. Lyon: IARC Press; 2004.

14. Miyake $\mathrm{H}$, Nakamura $\mathrm{H}, \mathrm{Hara}$ I, et al. Multifocal renal cell carcinoma: evidence for a common clonal origin. Clin Cancer Res 1998;4:2491 - 4

15. Junker K,Thrum K, SchlichterA, Muller G, Hindermann
W, Schubert J. Clonal origin of multifocal renal cell carcinoma as determined by microsatellite analysis. J Urol 2002;168:2632-6.

16. Dimarco DS, Lohse CM, Zincke H, Cheville JC Blute ML. Long-term survival of patients with unilateral sporadic multifocal renal cell carcinoma according to histologic subtype compared with patients with solitary tumors after radical nephrectomy. Urology 2004;64:462-7.

17. Blute ML, Thibault GP, Leibovich BC, Cheville JC, Lohse CM, Zincke H. Multiple ipsilateral renal tumors discovered at planned nephron sparing surgery: importance of tumor histology and risk of metachronous recurrence. J Urol 2003;170:760-3.

18. Blute $\mathrm{ML}$, Itano NB, Cheville JC, Weaver AL, Lohse $\mathrm{CM}$, Zincke $\mathrm{H}$. The effect of bilaterality, pathological features and surgical outcome in nonhereditary renal cell carcinoma. J Urol 2003;169:1276-81.

19. Jones TD, Eble JN, Wang M, et al. Molecular genetic evidence for the independent origin of multifocal papillary tumors in patients with papillary renal cell carcinomas. Clin Cancer Res 2005;11:7226-33.

20. Greene FL, Page DL, Fleming ID, et al. American 
Joint Committee on Cancer Staging Manual. 6th ed. New York: Springer; 2002.

21. Fuhrman S, Lasky LC, Limas L. Prognostic significance of morphologic parameters in renal cell carcinoma. Am J Surg Pathol 1982;6:655-63.

22. Cheng $L$, Jones TD, McCarthy RP, et al. Molecular genetic evidence for a common clonal origin of urinary bladder small cell carcinoma and coexisting urothelial carcinoma. Am J Pathol 2005;166:1533-9.

23. Cheng $L$, Zhang $S$, Wang $M$, et al. Molecular genetic evidence supporting the neoplastic nature of stromal cells in "fibrosis" after chemotherapy for testicular germ cell tumors. J Pathol 2007:213:65-71.

24. Sung MT, Wang M, MacLennan GT, et al. Histogenesis of sarcomatoid urothelial carcinoma of the urinary bladder: evidence for a common clonal origin with divergent differentiation. J Pathol 2007;211:420-30.

25. Sung MT, Zhang S, MacLennan GT, et al. Histogenesis of clear cell adenocarcinoma in the urinary tract: Evidence of urothelial origin. Clin Cancer Res 2008; 14:1947-55.

26. Cheng L, Gu J, Eble JN, et al. Molecular genetic evidence for different clonal origin of components of human renal angiomyolipomas. Am J Surg Pathol 2001;25:1231-6.

27. Cheng L, MacLennan GT, Zhang S, Wang M, Pan CX, Koch MO. Laser capture microdissection analysis reveals frequent allelic losses in papillary urothelial neoplasm of low malignant potential of the urinary bladder. Cancer 2004;101:183-8.

28. Shridhar V, Sun QC, Miller OJ, Kalemkerian GP, Petros J, Smith DI. Loss of heterozygosity on the long arm of human chromosome 7 in sporadic renal cell carcinomas. Oncogene 1997:15:2727-33.

29. Junker K, Hindermann W, Schubert J, Schlichter A. Differentiation of multifocal renal cell carcinoma by comparative genomic hybridization. Anticancer Res 1999;19:1487-92.

30. Schraml P, Struckmann K, Bednar R, et al. CDKNA2A mutation analysis, protein expression, and deletion mapping of chromosome $9 p$ in conventional clear-cell renal carcinomas: evidence for a second tumor suppressor gene proximal to CDKN2A. Am J Pathol 2001;158:593-601.

31. Reiter RE, Anglard P, Liu S, Gnarra JR, Linehan WM. Chromosome 17p deletions and p53 mutations in renal cell carcinoma. Cancer Res 1993;53:3092-7.

32. Brandli DW, Ulbright TM, Foster RS, et al. Stroma adjacent to metastatic mature teratoma after chemotherapy for testicular germ cell tumors is derived from the same progenitor cells as the teratoma. Cancer Res 2003;63:6063-8

33. McCarthy RP, Zhang S, Bostwick DG, et al. Molecular genetic evidence for different clonal origins of epithelial and stromal components of phyllodes tumor of the prostate. Am J Pathol 2004;165:1395-400.

34. Cheng L, Bostwick DG, Li G, et al. Allelic imbalance in the clonal evolution of prostate carcinoma. Cancer 1999;85:2017-22.

35. Cheng L, Gu J, Ulbright TM, et al. Precise microdissection of human bladder carcinomas reveals divergent tumor subclones in the same tumor. Cancer 2002;94:104-10.

36. Cheng L, Shan A, Cheville JC, Qian J, Bostwick DG. Atypical adenomatous hyperplasia of the prostate: a premalignant lesion? Cancer Res 1998;58: 389-91.

37. Cheng L, Song SY, PretlowTG, et al. Evidence of independent origin of multiple tumors from patients with prostate cancer. J Natl Cancer Inst 1998;90:233-7.

38. Farrand K, Jovanovic $L$, Delahunt $B$, et al. Loss of heterozygosity studies revisited: prior quantification of the amplifiable DNA content of archival samples improves efficiency and reliability. J Mol Diagn 2002;4: $150-8$.

39. McCarthy RP, Wang $M$, Jones TD Strate RW Cheng L. Molecular evidence for the same clonal origin of multifocal papillary thyroid carcinomas. Clin Cancer Res 2006;12:2414-8.

40. Gu J, Roth LM, Younger C, et al. Molecular evidence for the independent origin of extra-ovarian papillary serous tumors of low malignant potential. J Natl Cancer Inst 2001;93:1147-52.

41. Cheng L, Zhang D. Molecular Genetic Pathology. Totowa (NJ): Humana Press/Springer; 2008.

42. Gobbo S, Eble JN, Martignoni G, et al. Clear cell papillary renal cell carcinoma: a distinct histopathological and molecular genetic entity. Am J Surg Pathol 2008;32:1239-45

43. Gobbo S, Eble JN, MacLennan GT, et al. Renal cell carcinomas with papillary architecture and clear cell components: the utility of immunohistochemical and cytogenetical analyses in differential diagnosis. Am J Surg Pathol 2008;32:1780-6.

44. Brunelli M, Gobbo S, Cossu-Rocca P, et al. Chromosomal gains in the sarcomatoid transformation of chromophobe renal cell carcinoma. Mod Pathol 2007:20:303-9.

45. Brunelli M, Eccher A, Gobbo S, et al. Loss of chromosome $9 p$ is an independent prognostic factor in patients with clear cell renal cell carcinoma. Mod Pathol 2008;21:1 -6.

46. Jones TD, Eble JN, Wang M, Maclennan GT, Jain S, Cheng L. Clonal divergence and genetic heterogeneity in clear cell renal cell carcinomas with sarcomatoid transformation. Cancer 2005;104:1195-203.

47. Cheng L, Zhang S, MacLennan GT, et al. Interphase fluorescence in situ hybridization analysis of chromosome $12 p$ abnormalities is useful for distinguishing epidermoid cysts of the testis from pure mature teratoma. Clin Cancer Res 2006;12:5668-72.

48. Brunelli M, Eble JN, Zhang $S$, Martignoni GLC. Gains of chromosomes 7, 17, 12, 16, and 20 and loss of $Y$ occur early in the evolution of papillary renal cell neoplasia: a fluorescent in situ hybridization study. Mod Pathol 2003;16:1053-9.

49. Kunju LP, Wojno K, Wolf JS, Jr., Cheng L, Shah RB. Papillary renal cell carcinoma with oncocytic cells and nonoverlapping low grade nuclei: expanding the morphologic spectrum with emphasis on clinicopathologic, immunohistochemical and molecular features. Hum Pathol 2008;39:96-101.

50. Cossu-Rocca P, Eble JN, Delahunt B, et al. Renal mucinous tubular and spindle carcinoma lacks the gains of chromosomes 7 and 17 and losses of chromosome $Y$ that are prevalent in papillary renal cell carcinoma. Mod Pathol 2006;19:488-93.

51. Cossu-Rocca P, Eble JN, Zhang S, Martignoni G, Brunelli M, Cheng L. Acquired cystic diseaseassociated renal tumors: an immunohistochemica and fluorescence in situ hybridization study. Mod Pathol 2006;19:780-7.

52. Prayson RA, Castilla EA, Hartke M, Pettay J, Tubbs $\mathrm{RR}$, Barnett GH. Chromosome 1p allelic loss by fluorescence in situ hybridization is not observed in dysembryoplastic neuroepithelial tumors. Am J Clin Pathol 2002;118:512-7.

53. Fallon KB, Palmer CA, Roth KA, et al. Prognostic value of $1 p, 19 q, 9 p, 10 q$, and EGFR-FISH analyses in recurrent oligodendrogliomas. J Neuropathol Exp Neurol 2004;63:314-22.

54. Jones J, Libermann TA. Genomics of renal cell cancer: the biology behind and the therapy ahead. Clin Cancer Res 2007;13:685-92s. 


\section{Clinical Cancer Research}

\section{Evidence for Polyclonal Origin of Multifocal Clear Cell Renal Cell Carcinoma}

Liang Cheng, Gregory T. MacLennan, Shaobo Zhang, et al.

Clin Cancer Res 2008;14:8087-8093.

Updated version Access the most recent version of this article at:

http://clincancerres.aacrjournals.org/content/14/24/8087

Cited articles This article cites 50 articles, 8 of which you can access for free at:

http://clincancerres.aacrjournals.org/content/14/24/8087.full\#ref-list-1

Citing articles This article has been cited by 1 HighWire-hosted articles. Access the articles at:

http://clincancerres.aacrjournals.org/content/14/24/8087.full\#related-urls

E-mail alerts Sign up to receive free email-alerts related to this article or journal.

Reprints and To order reprints of this article or to subscribe to the journal, contact the AACR Publications

Subscriptions Department at pubs@aacr.org.

Permissions To request permission to re-use all or part of this article, use this link http://clincancerres.aacrjournals.org/content/14/24/8087.

Click on "Request Permissions" which will take you to the Copyright Clearance Center's (CCC)

Rightslink site. 